\title{
OsPG1 Encodes a Polygalacturonase that Determines Cell Wall Architecture and Affects Resistance to Bacterial Blight Pathogen in Rice
}

\author{
Yongrun Cao ${ }^{1,2 \dagger}$, Yue Zhang ${ }^{1,2+}$, Yuyu Chen ${ }^{1,2}$, Ning Yu ${ }^{1,2}$, Shah Liaqat ${ }^{1,2}$, Weixun Wu $u^{1,2}$, Daibo Chen ${ }^{1,2}$,
} Shihua Cheng ${ }^{1,2}$, Xinghua Wei ${ }^{1,2}$, Liyong Cao ${ }^{1,2}$, Yingxin Zhang ${ }^{1,2^{*}}$ and Qunen Liu Li, $^{1,2^{*}}$ (D)

\begin{abstract}
Background: Plant cell walls are the main physical barrier encountered by pathogens colonizing plant tissues. Alteration of cell wall integrity $(\mathrm{CWI})$ can activate specific defenses by impairing proteins involved in cell wall biosynthesis, degradation and remodeling, or cell wall damage due to biotic or abiotic stress. Polygalacturonase (PG) depolymerize pectin by hydrolysis, thereby altering pectin composition and structures and activating cell wall defense. Although many studies of CWI have been reported, the mechanism of how PGs regulate cell wall immune response is not well understood.

Results: Necrosis appeared in leaf tips at the tillering stage, finally resulting in $3-5 \mathrm{~cm}$ of dark brown necrotic tissue. Itn-212 showed obvious cell death and accumulation of $\mathrm{H}_{2} \mathrm{O}_{2}$ in leaf tips. The defense responses were activated in Itn-212 to resist bacterial blight pathogen of rice. Map based cloning revealed that a single base substitution (G-A) in the first intron caused incorrect splicing of OsPG1, resulting in a necrotic phenotype. OsPG1 is constitutively expressed in all organs, and the wild-type phenotype was restored in complementation individuals and knockout of wild-type lines resulted in necrosis as in Itn- 212. Transmission electron microscopy showed that thicknesses of cell walls were significantly reduced and cell size and shape were significantly diminished in Itn-212.

Conclusion: These results demonstrate that OSPG1 encodes a $P G$ in response to the leaf tip necrosis phenotype of Itn-212. Loss-of-function mutation of Itn-212 destroyed CWI, resulting in spontaneous cell death and an auto-activated defense response including reactive oxygen species (ROS) burst and pathogenesisrelated (PR) gene expression, as well as enhanced resistance to Xanthomonas oryzae pv. oryzae (Xoo). These findings promote our understanding of the CWI mediated defense response.
\end{abstract}

Keywords: Rice, Leaf tip necrosis, Polygalacturonase, Bacterial blight, Cell wall

\footnotetext{
*Correspondence: zhangyingxin@caas.cn; liuqunen202@163.com

${ }^{\dagger}$ Yongrun Cao and Yue Zhang contributed equally to this work.

'State Key Laboratory of Rice Biology, China National Rice Research Institute,

Zhejiang 310006, Hangzhou, China

Full list of author information is available at the end of the article
}

\section{Springer Open}

(-) The Author(s). 2021 Open Access This article is licensed under a Creative Commons Attribution 4.0 International License, which permits use, sharing, adaptation, distribution and reproduction in any medium or format, as long as you give appropriate credit to the original author(s) and the source, provide a link to the Creative Commons licence, and indicate if changes were made. The images or other third party material in this article are included in the article's Creative Commons licence, unless indicated otherwise in a credit line to the material. If material is not included in the article's Creative Commons licence and your intended use is not permitted by statutory regulation or exceeds the permitted use, you will need to obtain permission directly from the copyright holder. To view a copy of this licence, visit http://creativecommons.org/licenses/by/4.0/. 


\section{Introduction}

Rice (Oryza sativa L.) is not only the world's most important food crop for more than half of the world's population, but also a model species for genetic, cytological, and agricultural studies (Itoh et al. 2005). As the main photosynthetic organs, the development status of rice leaves is closely related to the final yield. Premature withering of rice leaves has a significant impact on plant growth and yield. Thus, understanding the molecular mechanisms of leaf development and identifying genes causing premature withering are of great interest to both plant biologists and plant breeders.

Leaf necrosis starts to appear mainly at the apical meristem. The necrotic tips may be a specific regulation of the plant response to changes in the external environment or gene expression in vivo. The factors that induce leaf tip necrosis have been described at a molecular level in recent studies. The ectopic content of elements may result in leaf tip necrosis. The rice leaf tip necrosis 1 (ltn 1) mutant results in excessive accumulation of phosphate in shoots and thus causes plants to develop a leaf tip necrotic phenotype ( $\mathrm{Hu}$ et al. 2011). OsPT8 is involved in phosphate homeostasis in rice, and overexpressing OSPT8 resulted in excessive phosphate in shoots and chlorosis and necrosis in leaf tips under high phosphate (0.3 mM) supply (Jia et al. 2011).

Leaf tip necrosis or withering usually occur at the beginning of leaf senescence. A rice mutant Leaf Tip Senescence 1 (LTS1) resulted in dwarfism and withered leaf tips, ultimately causing early leaf senescence (Wu et al. 2016). The loss of function of DEL1 resulted in the leaf apex and leaf margin exhibiting a faint yellow color after germinating for 5 days, while leaf tips exhibited withering and cracking at the maturity stage (Leng et al. 2017). The phenotype of necrotic leaf tips correlates with plant resistance. Lr34 confers durable and partial field resistance to wheat against an obligate biotroph associated with leaf tip necrosis (Singh. 1992). Transforming resistant Lr34 into Nipponbare allele showed increased resistance against multiple isolates of Magnaporthe oryzae and plants also developed a typical, senescence-based leaf tip necrosis phenotype (Krattinger et al. 2016). The same phenotype also occurred in transgenic barley with Lr34 (Risk et al. 2013). Necrotic leaves caused by programmed cell death (PCD) also alter cell wall structure. Mutation of a PECTATE LYASE-LIKE gene. DEL1, led to PCD and changes in cell wall composition and structure in rice (Leng et al. 2017). In other cases, the cell wall is degraded in abscission zones and is a key event in lace plant PCD (Gunawardena et al. 2007).

The typical plant cell wall consists of a primary cell wall, secondary cell wall and middle lamella, comprised of various carbohydrate-based polymers (cellulose, pectins and hemicelluloses) (Sarkar et al. 2009). PGs belong to one of the largest hydrolase families (GH28) and are expressed in a wide range of tissues and developmental stages in plants and fungus (Markovic and Janecek. 2001). PGs are one of the primary cell wall hydrolases affecting cell wall architecture by degrading pectin (Micheli. 2001). PGs have been identified to have multiple functions in a diverse range of processes including fruit ripening, organ abscission, pollen maturation, pathogen infection and plant resistance to pathogens (Atkinson et al. 2002; Wang et al. 2005; Villarreal et al.; 2009). For example, MdPG1 and MdPG2 regulate apple fruit softening and are induced by ethylene (Wakasa et al. 2006; Li et al. 2010). FaPG1 was up-regulated during strawberry fruit ripening and silencing FaPG1 by antisense transformation significantly reduced strawberry fruit softening (Quesada et al. 2009). Downregulation of $P p B G A L 10$ and PpBGAL16 expression inhibited cell wall degradation and ethylene production and delayed peach fruit softening by decreasing PG and pectin methyl esterases (PME) activity (Liu et al. 2018).

In Arabidopsis, PGs mainly function in growth and developmental processes including cell separation and expansion. ARABIDOPSIS DEHISCENCE ZONE POLYGALACTURONASE 1 (ADPG1) and ADPG2 are essential for silique dehiscence; $A D P G 2$ and QUARTET2 (QRT2) contribute to floral organ abscission; and all three genes contribute to anther dehiscence (Ogawa et al. 2009). Mutation of QRT3 resulted in failure of microspore separation during pollen development (Rhee et al. 2003). POLYGALACTURONASE INVOLVED IN EXPANSION1 (PGX1) and PGX2 function in cell expansion in seedling growth and rosette expansion in adult plants; overexpressing them resulted in enhanced hypocotyl elongation (Xiao et al. 2014; Xiao et al., 2017). Different from the two previously characterized PGX genes, PGX3 functions in seed germination, which contributes to the determination of etiolated hypocotyl length and root length in young seedlings (Rui et al. 2017). Microbial PGs stimulate plant cell walls to release oligogalacturonides (OGs) to activate defense responses during infections. Phytopathogenic fungi secrete PGs to degrade the pectic homogalacturonan (HG) backbone and aid host colonization by degrading CWI (Annis and Goodwin. 1997). Transgenic expression of a fungal PG in tobacco and Arabidopsis results in higher resistance to microbial pathogens and constitutively activated defense responses (Ferrari et al. 2007).

Although many PGs have been genetically and biochemically characterized in plants, few studies investigating PGs in rice have been reported. OsBURP16 belongs to the PG1 $\beta$-like subfamily of BURP-family genes and encodes one putative PG1 $\beta$ subunit precursor, which showed enhanced PG activity and reduced pectin 
content and increased abiotic stress sensitivity in rice when it was overexpressed (Liu et al. 2014). In this study, we report the isolation of a leaf tip necrosis mutant named $l t n-212$ that exhibits necrotic leaf tips. The mutation in ltn-212 led to $\mathrm{H}_{2} \mathrm{O}_{2}$ accumulation and cell death in the necrotic part, but also caused enhanced resistance to bacterial blight pathogen Xoo. Using a mapbased cloning strategy, we isolated the gene that encodes OsPG1. Our data suggested that OsPG1 is responsible for leaf tip necrosis in $l t n-212$ and functions directly in defense responses by mediating cell wall structure.

\section{Results}

\section{Phenotypic Characteristics of Itn-212}

We isolated a leaf tip necrosis mutant from an ethyl methane sulfonate (EMS)-derived mutant population in the JiaHe212 background, which we named ltn-212 (leaf tip necrosis). Under natural summer field conditions, the leaf tip of $l t n-212$ had a small necrosis region and dark brown necrotic spots were formed at the tillering stage (Additional file 1: Figure S1A-B). Necrosis or withering at the leaf tip is typically the beginning of plant senescence and extends to the bottom of the leaf as the plant grows. Unlike other plant materials, initial necrosis of $l t n-212$ only occurred at all leaf tips at the tillering stage and developed into $3-5 \mathrm{~cm}$ of dark brown necrotic tissue until ripening stage (Fig. 1a-c). In general, the necrosis changed during plant growth but was limited to the leaf tip in $l$ tn-212.

The leaf is the mainly photosynthetic organ for energy assimilation of rice. As a result, ltn-212 significantly reduced plant height, 1000-grain weight, and grain length, compared to wild-type (WT, JiaHe212), but there were no changes in grain width or tiller number (Fig. 1d-e,

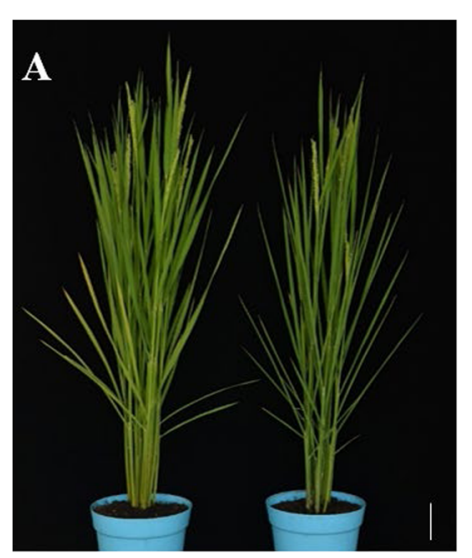

WT

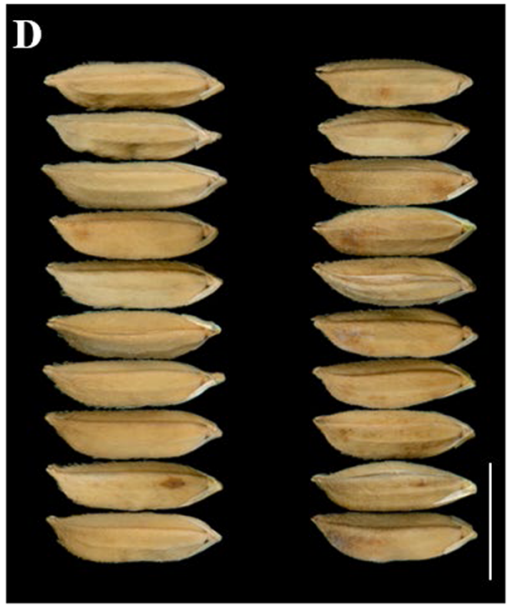

WT
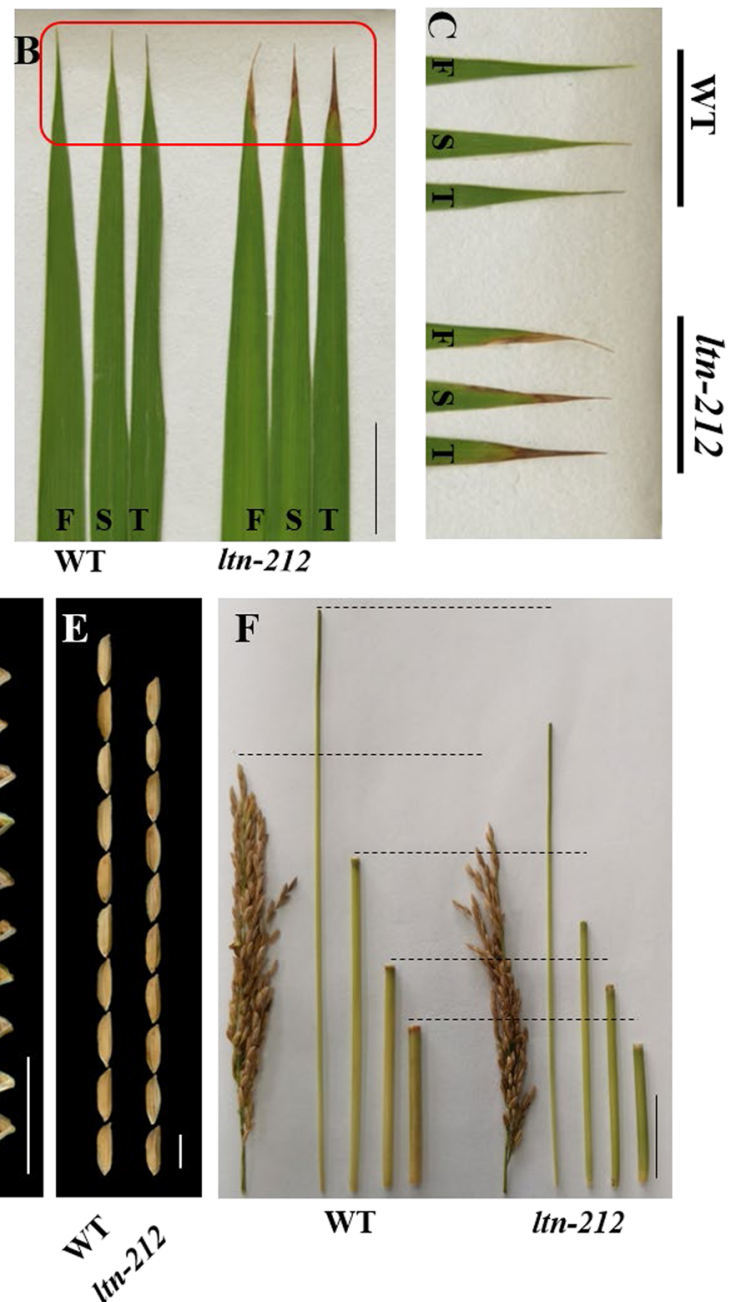

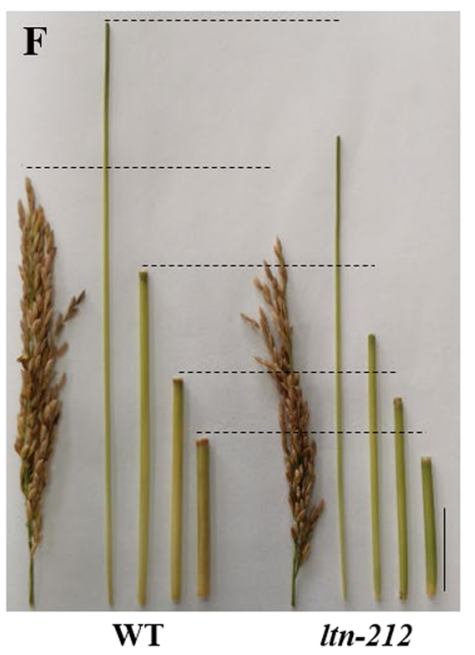

WT

ltn-212

Fig. 1 Leaf tip necrosis and agronomic traits of Itn-212. a Phenotype of WT and Itn-212 at heading stage (scale bar $=10 \mathrm{~cm}$ ). $\mathbf{b}$ Leaf tip necrosis identification of WT and Itn-212 at heading stage (scale bar $=5 \mathrm{~cm}$ ). $\mathbf{c}$ Enlarge of red part of Fig. b. d-e The phenotype of grain width and grain length (scale bar $=10 \mathrm{~mm}$ ). $\mathbf{f}$ Comparison of panicles and culm length of WT and Itn-212 (scale bar $=5 \mathrm{~cm}){ }^{* *}$ indicates significance at $P \leq 0.01$ and * indicates significance at $P \leq 0.05$ (Student's $t$ test). F: The first top leaf. S: The second top leaf. T: The third top leaf 
Additional file 1: Figure S2A-D). The reduced plant height for $l t n-212$ was due to shortened panicles along with shortened first three internodes compared with WT (Fig. 1f, Additional file 1: Figure S2E). The data suggested that the leaf-necrosis mutation also significantly affected agronomic performance.

\section{$\mathrm{H}_{2} \mathrm{O}_{2}$ Accumulation and Cell Death Occur in Itn-212}

Necrosis has been defined as a type of cell death, mainly caused by ROS burst and $\mathrm{H}_{2} \mathrm{O}_{2}$ accumulation (Van and Dat, 2006). To determine whether the development of necrosis in ltn-212 involves altered $\mathrm{H}_{2} \mathrm{O}_{2}$ accumulation and cell death, we performed 3,3-Diaminobenzidine (DAB) and Evans blue staining. DAB staining results in the formation of reddish-brown formazan precipitates indicative of $\mathrm{H}_{2} \mathrm{O}_{2}$ accumulation. The red brown precipitate was observed on the ltn-212 leaf tip, whereas no precipitate was observed in WT (Fig. 2a). In addition, the $\mathrm{H}_{2} \mathrm{O}_{2}$ contents in the $l t n-212$ leaf tips was approximately 3 -fold higher than in WT leaf tips (Fig. 2c). Evans blue staining is an indicator of irreversible membrane damage or cell death (Liu et al. 2008). The ltn-212 leaf tip with necrosis had blue stained cells, whereas no staining was observed in $l t n-212$ leaves without necrosis or WT (Fig. 2b). To confirm membrane damage and cell death, we further measured the levels of malonaldehyde (MDA). The $l t n-212$ mutant showed significantly higher levels of MDA content compared to WT (Fig. 2d).

Plants can remove ROS by synthesizing anti-oxidative enzymes when injured and suffering from stress. We quantitatively determined the activity of these enzymes in $l t n-212$ and WT leaves. The results indicated that content of total protein significantly decreased in $l t n-212$ compared to WT. The activities of catalase (CAT) and superoxide dismutase (SOD) and peroxidase (POD) increased in ltn-212 plants, by $17.15 \mathrm{U} / \mathrm{mgprot}, 1.28 \mathrm{U} /$ mgprot and $32.35 \mathrm{U} / \mathrm{mgprot}$ in ltn-212 leaf tips, respectively, which were approximately $2.1-, 1.6-$ and 1.5 -fold higher than the levels of $8.08 \mathrm{U} / \mathrm{mgprot}, 0.82 \mathrm{U} / \mathrm{mgprot}$ and 21.19 U/mgprot in the WT, respectively (Fig. 2e-h). Taken together, these results demonstrate that the formation of leaf necrosis was associated with ROS accumulation and irreversible membrane damage in the $l t n$ 212 cells.

\section{Activation of Defense Responses in Itn-212}

Accumulation of ROS commonly activates defense responses that result in enhanced resistance to one or more pathogens. To examine whether the $l t n-212 \mathrm{mu}-$ tant also gains disease resistance, we inoculated the mutant and the WT plants with isolates of three Xoo pathotypes virulent against the WT using the leaf clipping method at the tillering stage. The results showed that $l t n-212$ exhibited significantly enhanced resistance to races CR1, CR4, and PXO96 compared to WT (Fig. 3a-b). To check whether the enhanced disease resistance response stemmed from elevated expression of defense related genes, we measured the expression of nine PR genes by real-time quantitative PCR analysis. These genes were mainly involved in SA and JA signaling pathways. The results showed the mRNA levels of OsJAZ1, OsPR1a, OsPR1b, OsPR5 and OsPO-C1 significantly increased compared to WT; in particular, the expression of OsPR $1 b$ was upregulated 15-fold in $l t n-212$ compared to WT (Fig. 3c). Thus, we speculated that the leaf tip necrosis also triggered a defense response, resulting in enhanced resistance to Xoo in ltn-212.

\section{Map-Based Cloning of OsPG1}

To determine the genetic control of the mutation, we crossed $l t n-212$ and the WT JiaHe212. $\mathrm{F}_{1}$ progenies had a normal phenotype matching that of WT and in the $F_{2}$ segregating populations, normal and mutant phenotypes showed a typical segregation ratio of 3:1 (158:42, $\chi^{2}=$ 1.56), indicating that the leaf tip necrotic phenotype of ltn-212 was controlled by a single recessive nuclear gene. To map the gene responsible for the ltn-212 mutant phenotypes, an $\mathrm{F}_{2}$ mapping population was constructed by crossing ltn-212 with the indica variety ZH8015. Eight $\mathrm{F}_{2}$ plants with the $l t n-212$ phenotype were used for primary mapping, and the mutation was located on the short arm of chromosome 1 between markers 1-12 and RM493 (Fig. 4a). By using 75 homozygous mutant plants, the mutation was further located to markers YSSR54 and YSSR41 (Fig. 4a). Subsequently, using an additional $939 \mathrm{~F}_{2}$ mutant individuals and three newly developed polymorphic markers, the mutation was finally narrowed down to an approximately $169 \mathrm{~Kb}$ region between markers YJK28 and YSSR41 (Fig. 4a). Twentyseven open reading frames (ORFs) were predicted in this region (Fig. 4a).

Sequencing and comparison of those ORFs cloned from $l t n-212$ and WT revealed that the seventh ORF (LOC_Os01g19170) had a single base substitution (G-A) in the first intron (Fig. 4b, Additional file 1 Figure S3). We then sequenced cDNA of LOC_OsO1g19170 from both genotypes. The sequence alignment revealed that the mutation disrupted the recognition site for an exon, causing incorrect splicing $28 \mathrm{bp}$ at the first exon in $l t n$ 212 (Fig. 4b, Additional file 1: Figure S3). This splicing error was predicted to introduce a premature stop codon at the 240th amino acid (Fig. 4c). We performed qRTPCR to understand if the mutation caused changes in expression of OsPG1 and the expression level in leaves at different positions. The expression of OsPG1 was significantly down-regulated in $l t n-212$ leaves compared to WT leaves and the mRNA level was highest in leaf tips 


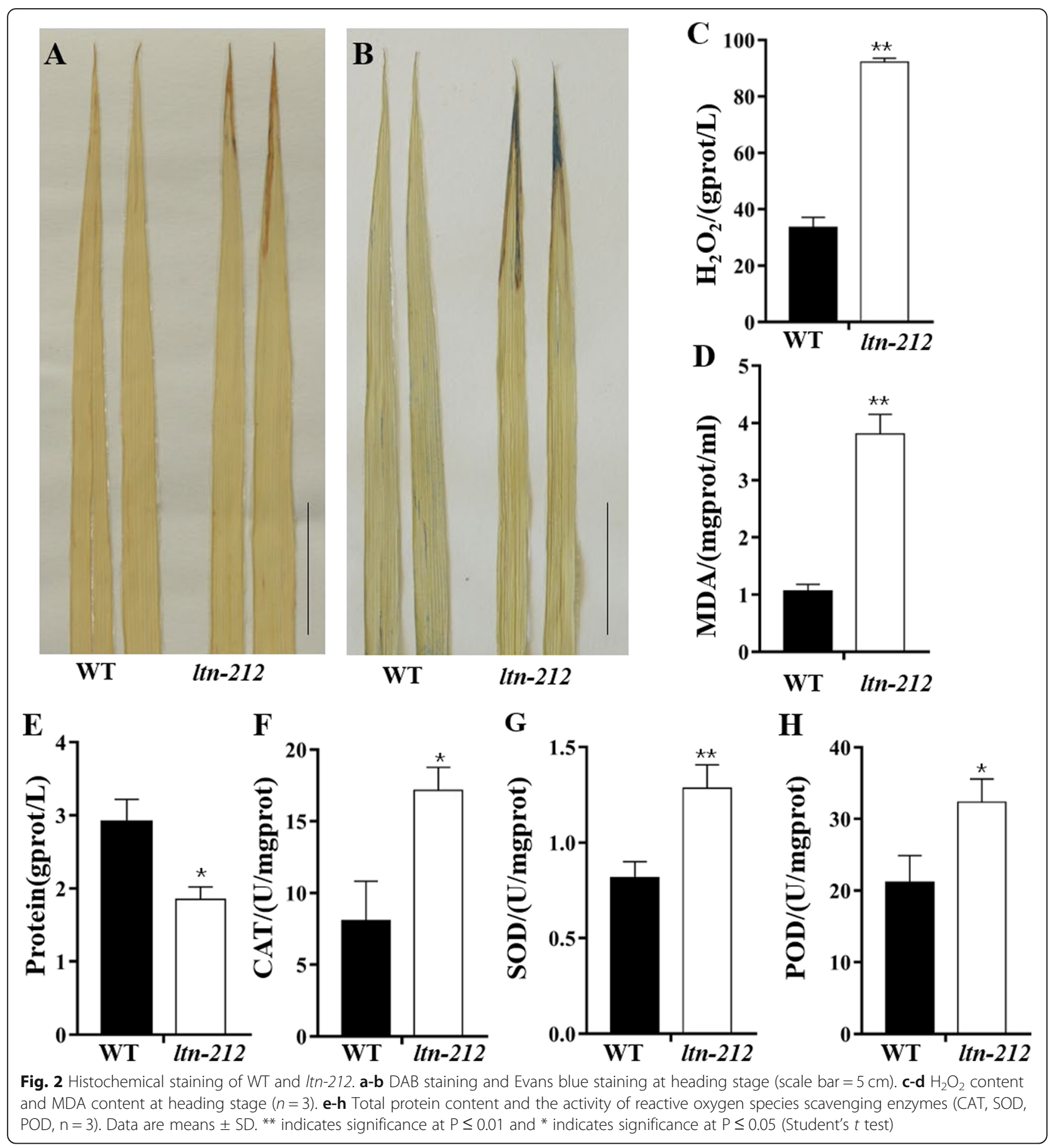

(Fig. 4d-e). On the basis of these data, we speculated that OsPG1 was responsible for the necrotic leaf tips.

\section{Functional Analysis and Verification of OsPG1}

To verify whether the incorrect splicing of OsPG1 was responsible for the $l t n-212$ phenotype, we constructed a complementation vector containing a WT-derived 5790 bp genomic DNA fragment consisting of the entire OsPG1 coding region, $2826 \mathrm{bp}$ upstream and $1098 \mathrm{bp}$ downstream sequences, and introduced it into ltn-212 using Agrobacterium-mediated transformation. The resulting complemented plants are referred to as $l t n$ 212-COM. No necrosis appeared on the leaf tip of any ltn-212-COM plants at any point in the life cycle (Fig. 5a-b). We carried out genotyping of $\mathrm{T}_{1}$ plants with no necrosis to check for the transgene by sequencing the region of OsPG1 that contains the mutation. We found that all progenies were heterozygous at the mutation site 


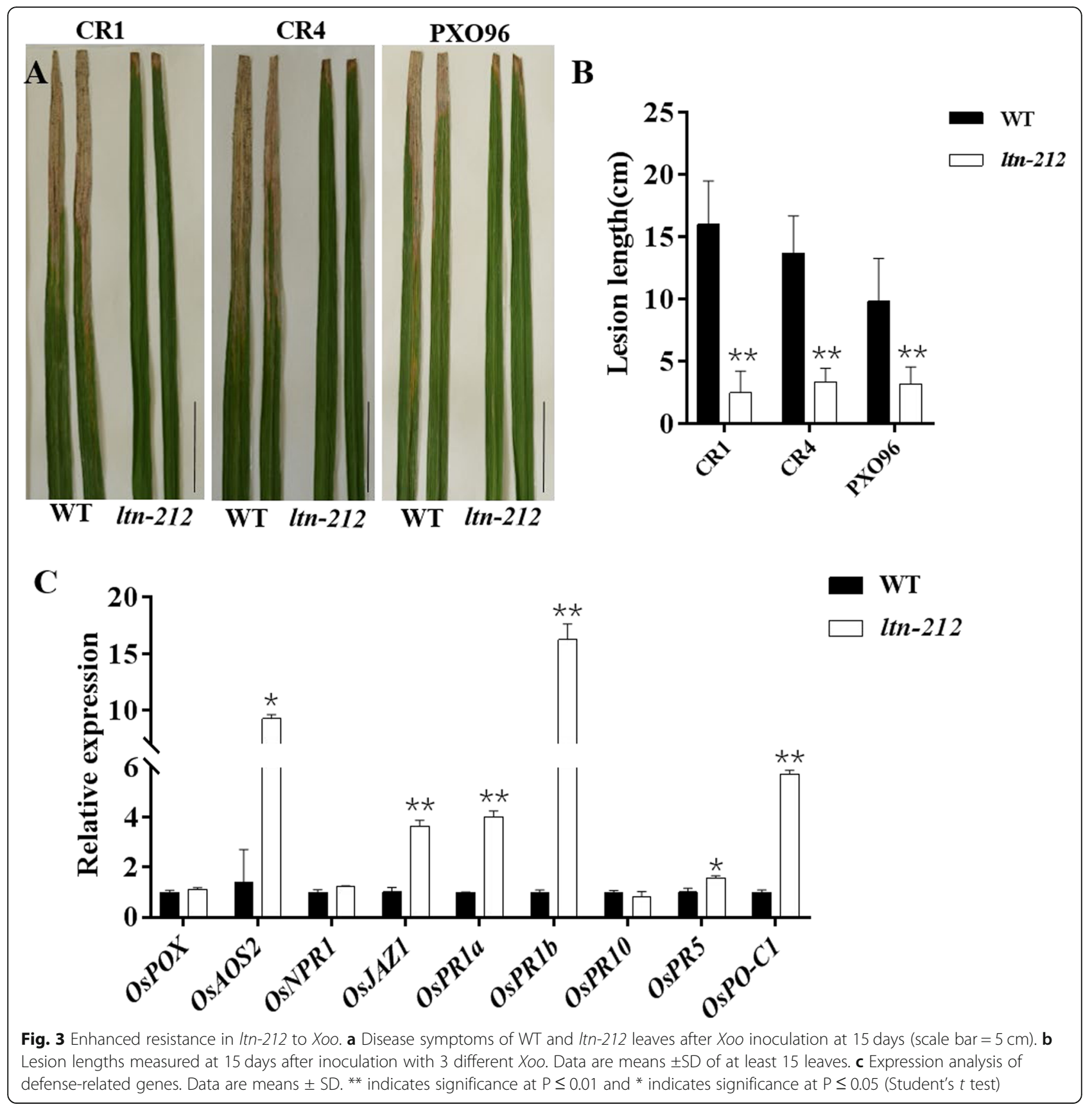

(Fig. 5e). Furthermore, we transformed a CRISPR-Cas9 construct targeting the first exon of OsPG1 into the WT, and obtained OsPG1 knock-out individuals (Fig. 5c-d). All the knockout plants exhibited the leaf tip necrotic phenotype (Fig. 5c-d, e). Together, our results indicate the mutation of OsPG1 was responsible for the formation of the necrotic leaf tip.

Sequence comparison between genomic DNA and cDNA showed that OsPG1 is composed of three exons separated by two introns. The coding sequence (CDS) of OsPG1 consists of 1512 nucleotides, and encodes a putative PG with a 504 amino acid protein. PG is one of the hydrolases of pectin and is involved in controlling the stability of cell wall structure. The typical PG genes in plants and fungi have four conserved domains: Domain I (SPNTDG), Domain II (GDDC), Domain III (CGPGHG ISIGSLG), and Domain IV (RIK). Sequence alignment of PGs homologous among rice, Arabidopsis thaliana, Brassica rapa L. ssp. pekinensis, Ciboria shiraiana, Rhizoctonia solani, and Glycine max revealed that OsPG1 was highly conserved (Additional file 1: Figure. S4). The rice genome contains 45 PG-like genes. Phylogenetic analysis of the PG in rice showed that OsPG1 was classified into Clade A. Genes in Clade A are mainly 


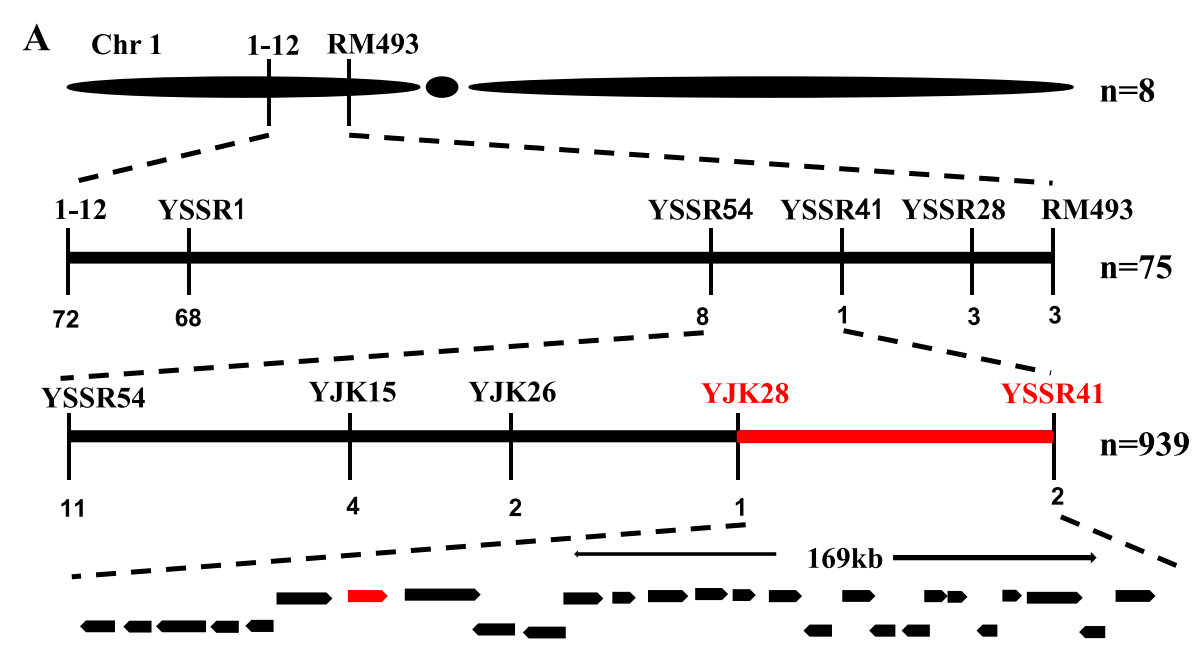

B

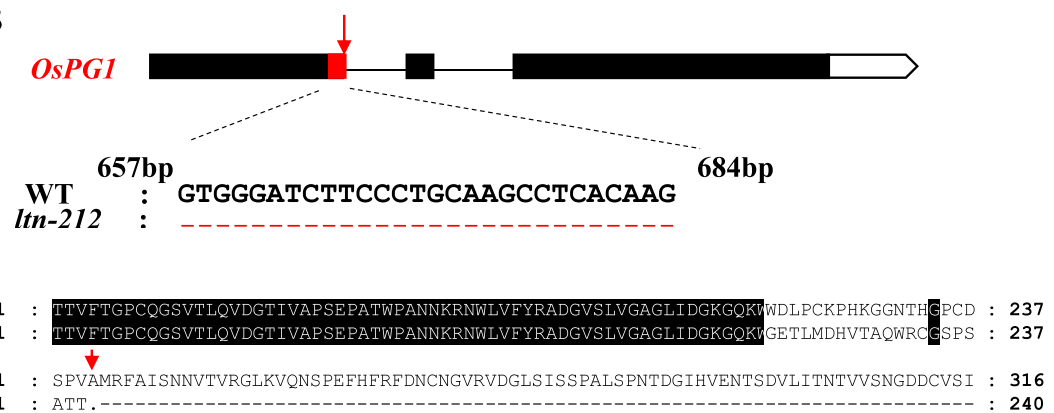

D

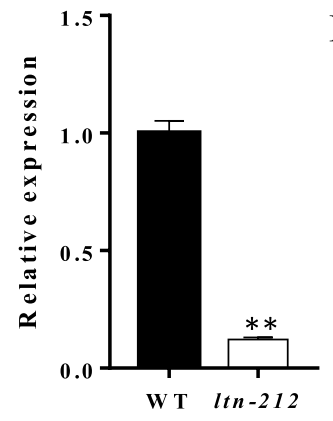

$\mathbf{E}$

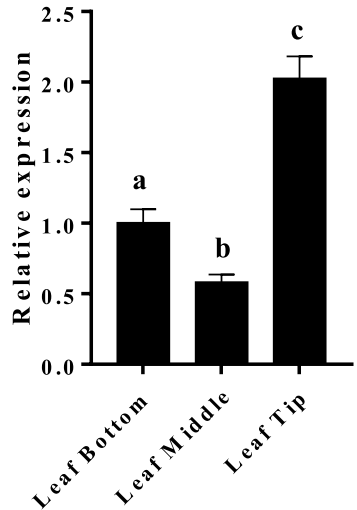

Fig. 4 Cloning analysis of the OsPG1. a Fine mapping of OsPG1. b Gene structure and the mutation of genome and CDNA in OsPG1. The red arrow indicates the mutant site and the red dotted line indicates the incorrected splicing sequences. c Protein sequence alignment of OsPG1 and ospg1. d Expression analysis of OSPG1 in WT and Itn-212 leaves $(n=3)$. e Expression analysis of OsPG1 in WT leaf bottom, middle and tip $(n=3)$. Data are means \pm SD. ${ }^{* *}$ indicates significance at $P \leq 0.01$ and ${ }^{*}$ indicates significance at $P \leq 0.05 . \mathbf{a}, \mathbf{b}, \mathbf{c}$ indicates significance at $P \leq 0.01$ (Student's $t$ test)

expressed at fruiting and abscission (Additional file 1 Figure S5). The results indicate that OsPG1 is a typical PG gene.

\section{Expression Pattern of OsPG1}

To elucidate the spatial and developmental expression pattern of OsPG1 in rice, qRT-PCR assays were performed in roots, culm, leaves, sheath, young panicles, mature panicles in the WT. OsPG1 was highly expressed in the roots, culm, sheath and young panicles while expression was barely detectable in leaves and mature panicles (Fig. $5 \mathrm{~g}$ ). We generated transgenic plants of OsPG1pro::GUS expressing the $\beta$-glucuronidase (GUS) reporter gene driven by the native promoter of OsPG1 to more precisely examine the spatial and temporal expression patterns of OsPG1. GUS staining showed activity of the OsPG1 promoter in all tissues examined (Fig. 5h). In summary, the results showed that OsPG1 was broadly expressed in all tissues. 

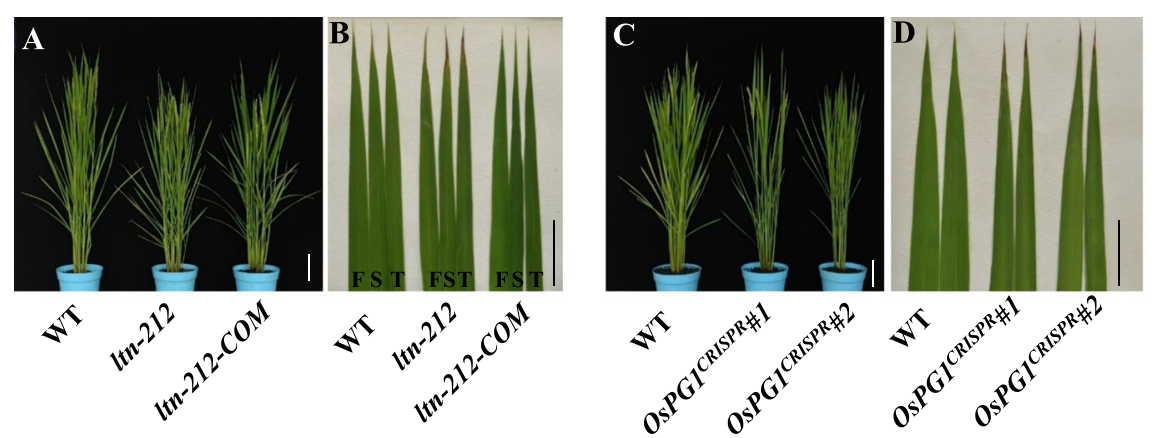

$\mathbf{E}$

$32 \mathrm{bp}$

$65 \mathrm{bp}$

WT : CCATTG-CGCTGCTTCTCGCGCTTGCCTTCGCGTC

OsPG1 CRISPR\#1 : CCATTGACGCTGCTTCTCGCGCTTGCCTTCGCGTC

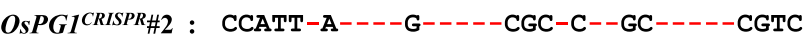

F

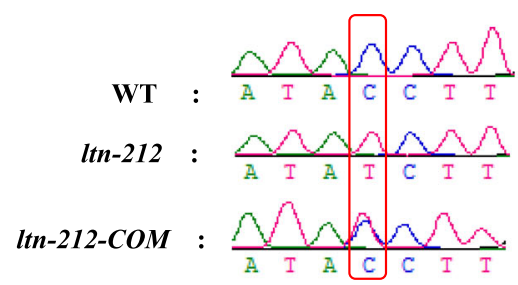

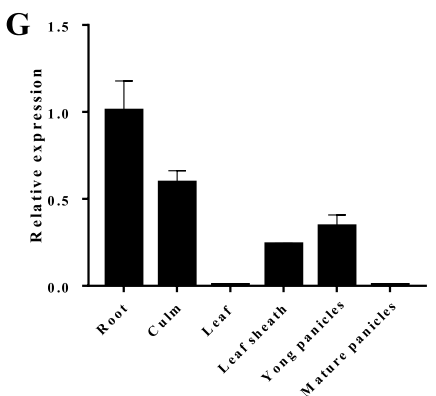

H
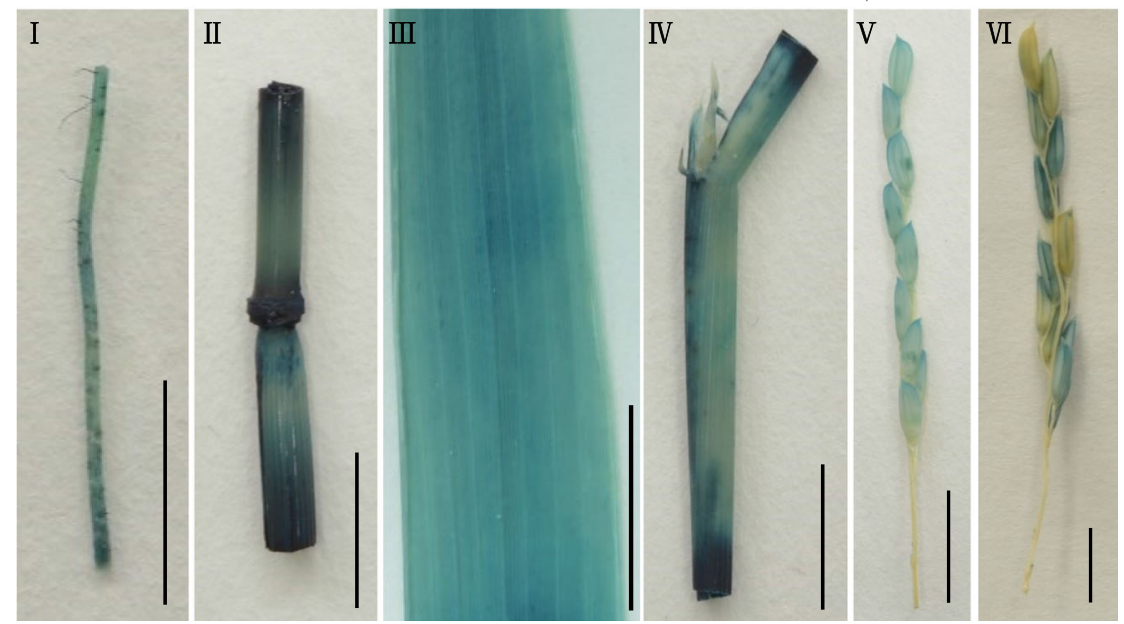

Fig. 5 Genetic complementation, knock-out and expression analysis of OsPG1. a Phenotype of WT, Itn-212 and $T_{1}$ complementation plant (scale $\mathrm{bar}=10 \mathrm{~cm}$ ). $\mathbf{b}$ Leaf tip necrosis disappear on the leaves of $\mathrm{T}_{1}$ complementation plant (scale bar $=5 \mathrm{~cm}$ ). $\mathbf{c}$ Phenotype of WT, and OsPG1 knock-

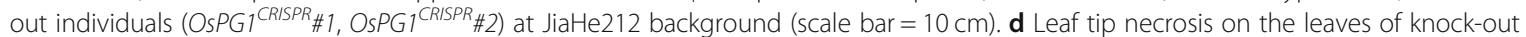

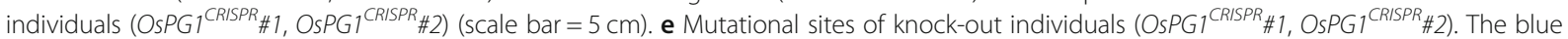
color words indicate target sequence and the red color words indicate insertion and deletion mutations. $\mathbf{f}$ The $T_{1}$ transgenic plants were verified by sequencing of the mutation site. $\mathbf{g}$ Expression levels of OSPG1 in various tissues $(\boldsymbol{n}=3)$. $\mathbf{h}$ Gus staining of OsPG1 promoter-GUS reporter transgenic plants (scale bar $=1 \mathrm{~cm}$ ). I: Roots. II:Colum. III: leaf. IV: Sheath. V: Young spikelet. VI: Mature spikelet. Data are means \pm SD. ${ }^{* *}$ indicates significance at $\mathrm{P} \leq 0.01$ and ${ }^{*}$ indicates significance at $\mathrm{P} \leq 0.05$ (Student's $t$ test)

\section{Mutation of OsPG1 Altered Cell Wall Structure and} Composition and Enhanced Resistance to Bacterial Blight Pathogen

Previous studies have demonstrated that pectin is fundamental and the most complex polysaccharide in plant cell walls (Bonnin et al., 2014). Functional analysis of
OsPG1 suggested that the cell wall structure in mutant plants may be altered. We therefore analyzed the structure of $l$ tn-212 and WT plants using Transmission Electron Microscope (TEM). The results revealed that the cell wall thicknesses of bundle sheath fiber cells in $l t n$ 212 were altered (Fig. 6a-d.). The thicknesses of the 

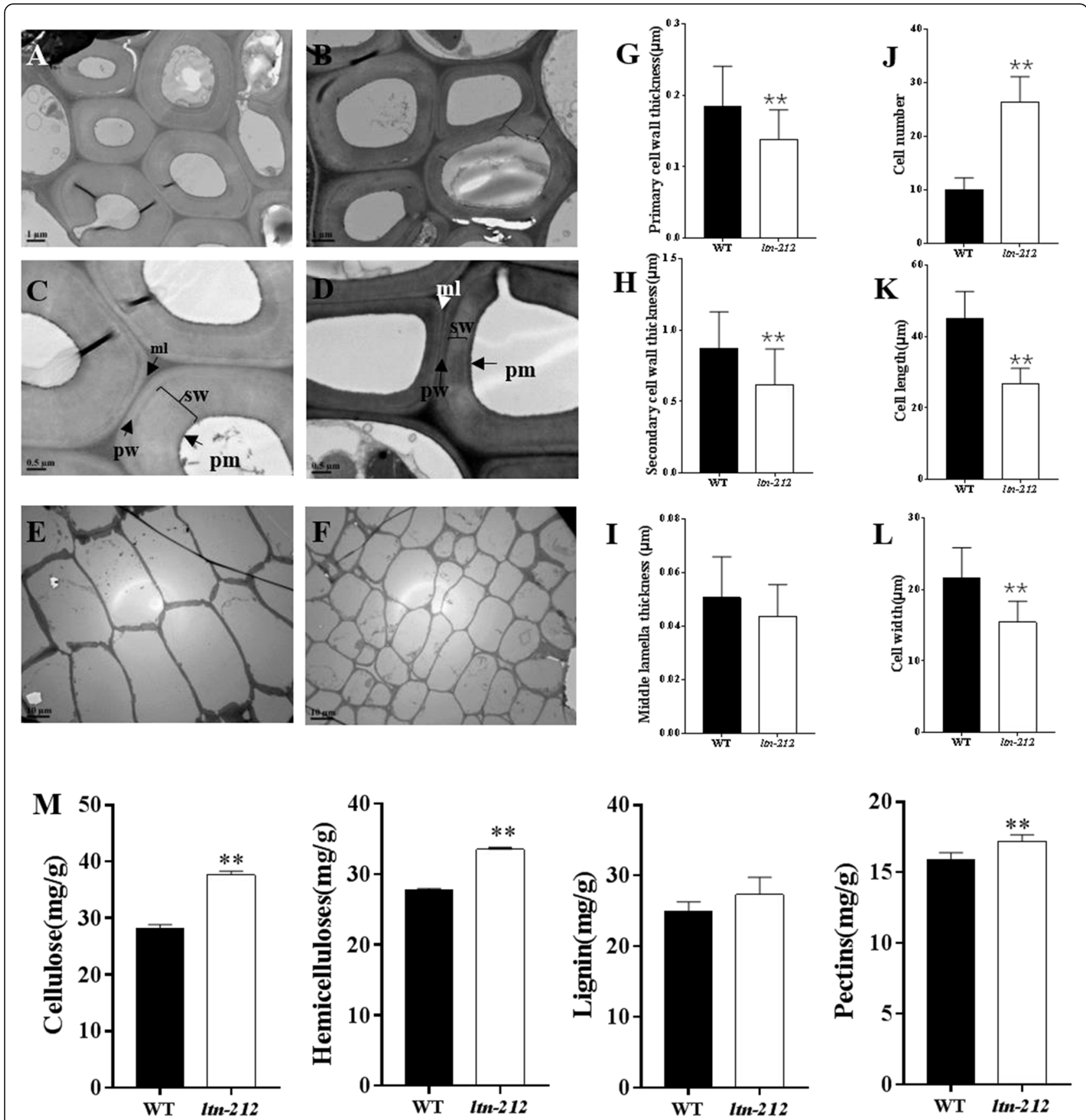

Fig. 6 Cell wall structure in WT and Itn-212. a-b TEM micrographs of the bundle sheath fiber cells in leaves of WT (a) and Itn-212 (b) (scale bar = $1 \mu \mathrm{m})$. c Magnification in (a), and D. magnification in (b) (scale bar $=0.5 \mu \mathrm{m})$. E-F. TEM micrographs of the internode cell of WT (e) and ltn-212 (f) (scale bar $=10 \mu \mathrm{m}$ ). $\mathbf{g}$-i Statistical analysis of the primary cell wall, secondary cell wall, and middle lamella thicknesses of bundle sheath fiber cells in leaves of WT and Itn-212. Data are means \pm SD of 20 cells. $\mathbf{j}-\mathbf{I}$ Statistical analysis of the cell number, cell length and cell width of WT and Itn212. Data are means \pm SD of 30 cells. $\mathbf{m}$ The cell wall composition of WT and Itn-212 $(n=5)$. ** indicates significance at $P \leq 0.01$ and * indicates significance at $\mathrm{P} \leq 0.05$ (Student's $t$ test). ml: middle lamella, pw: primary cell wall, sw: secondary cell wall, pm: plasma membrane

primary and secondary cell walls were reduced by $25.2 \%$ and $29.2 \%$ compared to WT, respectively, but there were no significant differences of middle lamella in ltn-212 and WT (Fig. 6g-i). The cell wall thickness in different leaf sites of $l t n-212$ were reduced compared to WT (Additional file 1: Figure. S6). Moreover, the results of
TEM in internodes showed that the cell numbers in $l t n$ 212 increased by approximately 2.6-fold compared to the levels in WT; the cell length and width were reduced by $40.6 \%$ and $39.6 \%$, respectively (Fig. $6 e-f, j-1$ ). To examine whether ospg1 affected cell wall composition, we analyzed the cellulose, hemicellulose, lignin and pectin 
contents of WT and $l t n-212$. The cellulose, hemicellulose and pectin contents of $l t n-212$ were increased by $33.6 \%, 20.8 \%$, and $8.1 \%$, respectively, while the lignin was no significantly changed (Fig. $6 \mathrm{~m}$ ). The results indicate OsPG1 mutation casues complex cell wall structure and composition altertion.

The cell wall is the first barrier against pathogen infection. To determine whether changes in cell wall structure enhanced resistance to the bacterial blight pathogen, we performed a disease resistance assessment with CR1, CR4, and PX096 of $l t n-212-C O M$ and OsPG1 ${ }^{\text {CRISPR }}$ plants. We observed that, similar to WT, the ltn-212-COM plants were more susceptible than $l t n-212$ plants to the compatible $X o o$, while OsPG1 ${ }^{C R I S P R}$ exhibited shorter lesions similar to those in $l t n-212$, compared to WT (Fig. 7a-b). These results suggest that the OsPG1 mutation causes

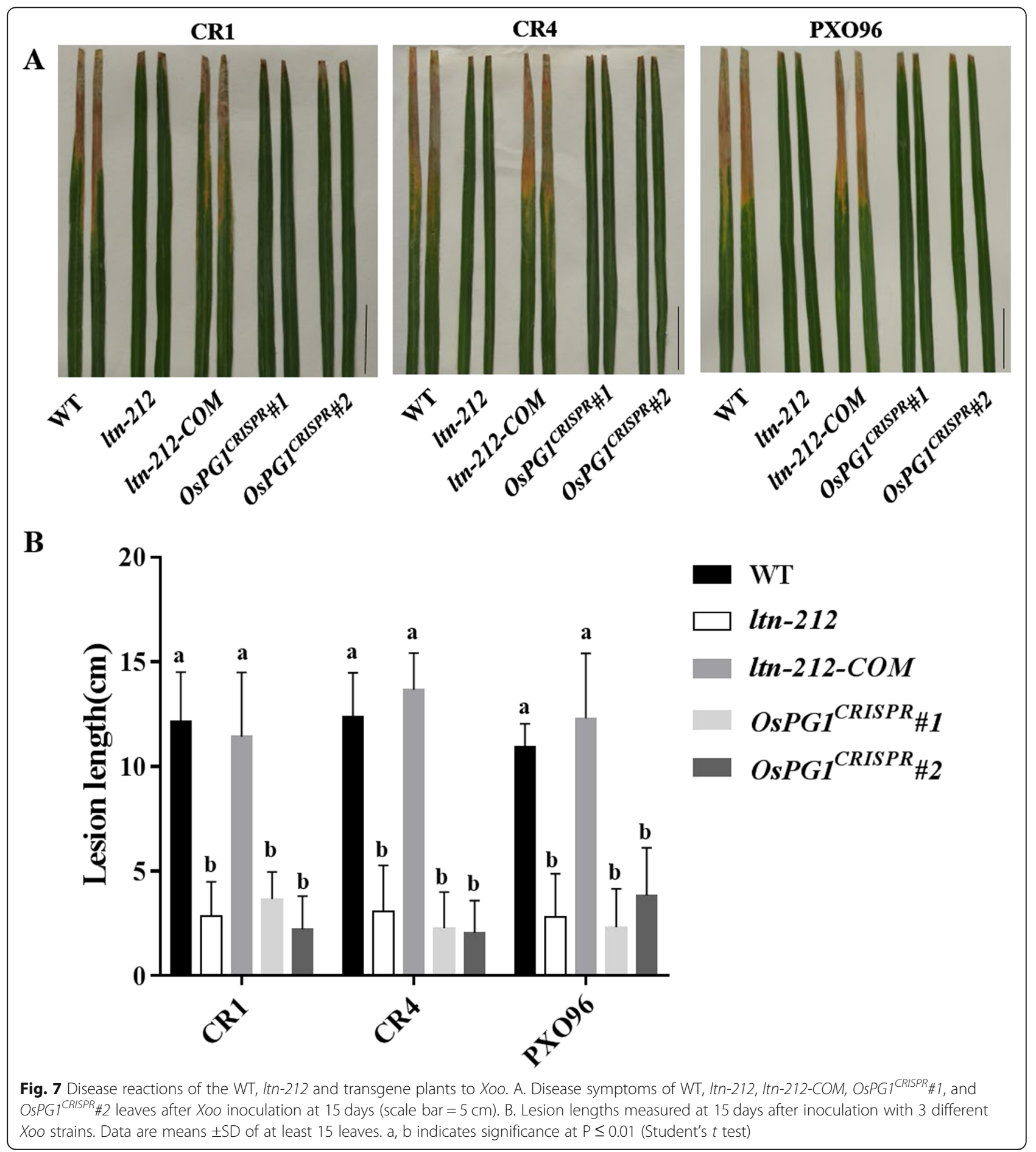


structural alterations in cell walls, and OsPG1 negatively regulates disease resistance in rice.

\section{Discussion}

It has been more than 50 years since the PG gene was first identified, but few PG genes have been reported in crops. In the present study, we identified a novel leaf tip necrotic mutant $l$ tn-212 in an EMS mutagenesis mutant population of rice cultivar JiaHe212. OsPG1 was identified as LOC_Os01g19170, which encodes a PG. Functional complementation and a knock out assay confirmed that the necrotic leaf tips were caused by incorrect splicing of OsPG1, indicating that OsPG1 functions directly in regulating normal leaf growth and development.

The necrosis or withering of leaves commonly accompanies PCD (Hong et al., 2018; Ruan et al., 2019). ZmPGH1, a PG gene homolog, functions as a suppressor of PCD in maize (He et al. 2019). ltn-212 showed dark brown necrotic spots in leaf tips at the tillering stage, which developed into $3-5 \mathrm{~cm}$ of dark brown necrosis. Evans blue staining and increased MDA content of ltn212 showed obvious cell death in leaf tips. TEM observation of the $l t n-212$ cells showed that areas without necrosis did not have cellular structure destruction or chloroplast degradation (Data not provide). Thus, we speculated that the necrotic leaf tips of $l t n-212$ were due to cell death and OsPG1 is a general suppressor of PCD in rice. The production of intracellular ROS is closely associated with cell death (Zurbriggen et al. 2010). As expected, DAB staining and $\mathrm{H}_{2} \mathrm{O}_{2}$ content in leaf tips occurred at higher levels in the $l t n-212$ mutants than in WT plants. To eliminate the accumulation of oxidative damage caused by ROS, plants have evolved ROS scavenging enzymes, like SOD, POD, and CAT. In the present study, the activities of three scavenging enzymes were significantly increased, which indicated that the balance between ROS production and scavenging was uncontrolled. ROS burst usually causes serious damage to plants, including brown spots, wilting and necrosis on leaves (Ma et al. 2019; Sathe et al. 2019; Rani et al., 2020). In $l t n-212$, the necrosis caused by uncontrolled ROS was confined to leaf tips. Interestingly, the qPCR results of OsPG1 in leaf showed that tips had the highest expression levels. This indicates that leaf tips have the highest mRNA levels, which might be responsible for tip necrosis.

PGs are essential in plant growth and development. In Arabidopsis, PGX1, PGX2 and PGX3 are all widely expressed in expanding tissues, including seedlings, roots, leaves, and flower, and all of the loss-of-function mutant plants have growth defects (Rui et al. 2017; Xiao et al. 2017; Xiao et al. 2014). In ltn-212, mutation of OsPG1 caused dark brown necrosis at leaf tips accompanied by decreased plant height, reduced spikelet length, and lower grain size and thousand seed weight relative to WT. This finding suggests that OsPG1 is distributed in multiple tissues at different developmental stages. Given the necrotic phenotype of leaf tips, and changes of cell morphology in internodes and agronomic traits, we speculate that OsPG1 affects apical development in rice. PGs comprise a large family, with 45 annotated PG-encoding genes in rice (Kim et al. 2006; Mccarthy et al. 2014). Phylogenetic analyses of PGs in rice revealed that OsPG1 is classified in Clade A, genes in this clade are expressed in the main fruit or abscission zone (Hadfield and Bennett. 1998). This result is consistent with the GUS staining of grains. Therefore, we conclude that the Clade A genes contributed multiple functions and might thus play a unique role in cell wall remodeling in leaves and other tissues.

Plant cell walls are complex and composed of polysaccharides and protein polymers (Somerville et al. 2004), which are essential in monitoring plant-pathogen interactions (Cantu et al. 2008; Malinovsky et al. 2014; Bacete et al. 2018). Plant cell walls are the first obstacle for pathogens attempting to infect plant tissues and thus function as a passive defensive barrier. Recent studies have shown that plant cell walls have mechanisms for maintaining CWI, including diverse sensors and pattern recognition receptors (PRRs) in the plasma membrane. Alteration of CWI by impairment of proteins involved in biosynthesis or remodeling cell walls significantly affect disease resistance or abiotic stresses (Bellincampi et al. 2014; Miedes et al. 2014; Kesten et al. 2017). PGs, a type of endogenous pectinases, catalyze the degradation of pectin via cleaving $\mathrm{HG}$ backbones in plant cell walls (Peaucelle et al. 2012). PGs are normally defined as pathogenicity factors, which are secreted by pathogens to facilitate degradation of the cell wall barrier and promote pathogenesis. However, plants also produce PG. In Arabidopsis, knockdown and overexpression of $A D P G 2$ impacts resistance to $P$. syringae (Wang et al. 2017). In $l t n-212$, we found that incorrect splicing of OsPG1 enhances the resistance to bacterial blight pathogen, meaning that the CWI could be altered in $l t n-212$ plants. The cell wall remodeling also results in PR gene expression. Ectopic activation of endogenous pectin degrading enzyme ADPG1 induces release of pectic oligosaccharide elicitors of PR gene expression (Gallegogiraldo et al. 2020). Similarly, we also detected that some PR genes were upregulated or down-regulated, which may be associated with CWI alteration. Our results 
highlight the importance of CWI in plant-pathogen interactions.

Pectins are a complex family of polysaccharides that make up a significant fraction of the plant primary cell wall and middle lamella (Bonnin et al. 2014; Atmodjo et al. 2013). Previous studies have shown that pectin has important functions involved in pollen tube growth, fruit softening, providing structural support, and promoting cell-to-cell adhesion and defense responses (Marinrodriguez et al. 2002; Wolf et al. 2009; Hongo et al. 2012). Many examples of disease susceptibility/resistance phenotypes have been reported. Mutations in pectate lyaselike gene PMR6 alter the composition of the plant cell wall and enhance resistance to powdery mildew in Arabidopsis (Vogel et al. 2002). Screening of mutants with alterations in cell wall monosaccharides indicated an important function of pectic polymers for penetration resistance and hyphal growth of Colletotrichum higginsianum at the biotrophic phase (Engelsdorf et al. 2016). Three pectin methylesterase genes AtPMEI10, AtPMEII1 and AtPMEI12 function as mediators maintaining CWI in Arabidopsis immunity (Lionetti et al. 2017). In this study, we observed that the thicknesses of the primary and secondary cell walls were significantly reduced in $l t n-212$ compared with WT. The changes in cell walls were probably caused by the loss of OsPG1 function, which leads to the degradation of pectin. Consistent with this, the cell numbers increased almost threefold, while the cell size and shape significantly decreased. These results indicate that the function of OsPG1 affects not only the cell wall, but also cell morphology.

Taking these findings together, it is clear that OsPG1 regulated cell death and plant immunity systems through cell wall remodeling. But given the complexity of cell walls, the details in CWI-mediated immunity are still incompletely understood.

\section{Conclusion}

OsPG1 functions as a suppressor of programmed cell death and affects CWI, which regulates plant immunity. This finding facilitates efforts to understand the biological functions of PGs, and the role of the cell wall in mediating defense responses.

\section{Methods}

\section{Plant Materials and Growth Conditions}

The wild-type used in this study was 'JiaHe212'(Oryza sativa L. ssp. japonica cv). The ltn-212 mutant was obtained from the mutant population generated by EMS treatment of JiaHe212. All plants used in this study were grown in paddy under natural conditions in Hangzhou, Zhejiang province and Lingshui, Hainan province, China. For disease characterizations, the plants were grown in a greenhouse with a photoperiod of $12 \mathrm{~h}$ white light at $30^{\circ} \mathrm{C}$ and $12 \mathrm{~h}$ dark at $25^{\circ} \mathrm{C}$.

\section{Construct for Complementation and CRISPR Vectors and Rice Transformation}

For the genetic complementation test, a 5790-bp genomic fragment covering the entire coding sequence and 2826-bp native promoter and 1098-bp terminator regions was amplified from the Japonica rice variety Jiahe212 genomic DNA by using KOD FX (Toyobo). The full length product was inserted to the pCAMBIA1300 vector using an In-Fusion Advantage Cloning kit (catalog no. PT4065; Clontech). For OsPG1 knockout vector construct and rice transformation entrusted BioRun company. The primer sequences used in this experiment listed in Additional file 1: Table S1.

\section{RNA Extraction and Quantitative Real-Time PCR (qRT-PCR) Analysis}

Total RNA was extracted from rice leaves, roots, stems at different developmental stages using the RNAprep Pure kit for plants (Tiangen, China). Frist-strand cDNA was synthesized with a ReverTra Ace qPCR RT kit (Toyobo). The qRT-PCR assays were performed with Lightcycler 480 SYBR green (Roche, Sweden) using a LightCycler 480 II real-time PCR instrument (Roche, Sweden). The expression level of the target genes was normalized to that of the UBQ gene. The sequences of all primers used for qRT-PCR are given in Additional file 1: Table S1.

\section{GUS Assay}

A $2.8-\mathrm{Kb}$ native promoter region of OsPG1 was amplified and inserted to the pCAMBIA 1305 vector. The transgene rice tissues were stained with GUS staining solution (50 mM PBS buffer; 10 mM EDTA, pH 8.0; 0.1\% Triton X-100; $1 \mathrm{mg} / \mathrm{mL}$ X-gluc; $1 \mathrm{mM}$ potassium ferricyanide; $1 \mathrm{mM}$ potassium ferrocyanide). After incubating at $37^{\circ} \mathrm{C}$ in the dark for $12 \mathrm{~h}$, the chlorophyll was removed by boiling in $95 \%$ ethanol until removed completely.

\section{DAB and Evans Blue Staining and Measurement of Enzymatic Activity Related Parameters}

Top leaves were collected at heading stage and immediately submerged in $10 \%$ SDS. After $10 \mathrm{~min}$, the leaves were subsequently submerged in a $1 \mathrm{mg} / \mathrm{mL}$ solution of $\mathrm{DAB}$ or $0.5 \mathrm{mg} / \mathrm{mL}$ solution of Evans Blue incubated for $8 \mathrm{~h}$ in the dark at room temperature, respectively. Samples were then decolored in $95 \%$ boiling ethanol for 30 min and soaked for $48 \mathrm{~h}$ in $95 \%$ ethanol until all of the chlorophyll had been removed. The cleared leaves were then photographed. 
Malondialdehyde (MDA) content, Peroxidase (POD), Super Oxide Dismutase (SOD), Catalase (CAT) activity, Soluble Protein (SP) and $\mathrm{H}_{2} \mathrm{O}_{2}$ content of wild type and ltn-212 top leaves were measured from heading stage plants and using kits from Nanjing Jiancheng Bioengineering Research Institute.

\section{Transmission Electron Microscopy (TEM) and Cell Wall Composition Analysis}

The materials were cut into small pieces and fixed in $2.5 \%$ glutaraldehyde and $0.1 \mathrm{M}$ phosphate buffer at $4{ }^{\circ} \mathrm{C}$ overnight and washed three times in the phosphate buffer $(0.1 \mathrm{M}, \mathrm{pH} 7.0)$ for $15 \mathrm{~min}$ at each step; postfixed with $1 \% \mathrm{OsO}_{4}$ in phosphate buffer for $1-2 \mathrm{~h}$ and washed three times in the phosphate buffer $(0.1 \mathrm{M}, \mathrm{pH} 7.0)$ for $15 \mathrm{~min}$ at each step. For TEM, the samples were subsequently dehydrated through a graded series of ethanol and then embedded in acrylic resin. Ultrathin sections $(70-90 \mathrm{~nm})$ were double stained with uranyl acetate and lead citrate aqueous solutions and observed with a Hitachi H-7650 transmission electron microscope (JEOL) at $80 \mathrm{kV}$. The content assay of cell wall components was entrusted to Convinced-Test company (Nanjing, China).

\section{Sequences Alignment and Phylogenetic Analyses}

The gDNA and cDNA sequences of OsPG1 and ospg1 were amplified from WT and $l t n-212$ using KOD FX, respectively. All the sequence alignments were used MegAlign and Gendoc software. The amino acid sequences of the OsPG1 and Homologous proteins were downloaded from NCBI BLAST server (http://www.ncbi. nlm.nih.gov/). Sequence alignment was performed with ClustalW (Additional file 1: Table S1). A neighborjoining method implemented in MEGA5 was used to generate the phylogenetic tree; the bootstrap values indicated at the nodes in the phylogenetic tree are based on 1000 replications.

\section{Pathogen Infection}

Rice plants were inoculated with Xoo by the leaf-clipping method. CR1, CR4, and PXO96 strains were separately suspended in distilled water and adjusted to $10^{9}$ viable cells $/ \mathrm{mL}(\mathrm{OD} 600=1)$. The Pathogen infection were performed as described previously (Liu et al. 2017).

\footnotetext{
Abbreviations

PG: Polygalacturonase; CWI: Cell wall integrity; ROS: Reactive oxygen species; PR: Pathogenesis-related; PCD: Programmed cell death;

OGs: Oligogalacturonides; PME: Pectin methyl esterases; DAB: 3,3-

Diaminobenzidine; MDA: Malonaldehyde; CAT: Catalase; POD: Peroxidase;

SOD: Superoxide dismutase; Xoo: Xanthomonas oryzae pv. oryzae; WT: Wild

type; ORF: Open reading frame; CDS: Coding sequence; GUS: $\beta$ -

glucuronidase; TEM: Transmission electron microscope; PRR: Pattern

recognition receptor
}

\section{Supplementary Information}

The online version contains supplementary material available at https://doi. org/10.1186/s12284-021-00478-9.

Additional file 1: Figure S1. Leaf tip necrosis of 1 tn-212 at tillering stage. A. Phenotype of WT and Itn-212 at tillering stage (scale bar $=10$ $\mathrm{cm}$ ). B. Leaf tip necrosis identification of WT and $/ \mathrm{tn}-212$ at tillering stage (scale bar $=5 \mathrm{~cm}$ ). Figure S2. Data statistics of agronomic traits. A-B. Comparison of tiller numbers and plant height of WT and Itn-212 $(n=10)$. C-D. Comparison of grain length and thousand grain weight of WT and Itn-212 $(n=10)$. E. Comparison of panicles and culm length of WT and Itn-212 $(n=10) .{ }^{* *}$ indicates significance at $P \leq 0.01$ and * indicates significance at $P \leq 0.05$ (Student's $t$ test). Figure $\mathbf{S 3}$. Genome DNA and CDNA alignments between WT and Itn-212. Red star indicates start codon and stop codon, respectively. The red box indicates the incorrected splicing sequences. The red arrow indicates the mutant site. Figure S4. Amino acid sequence alignment of PG homologous. ADPG2: Arabidopsis thaliana, BCMF9: Brassicarapa L. ssp. Pekinensis, CSPG1: Ciboria shiraiana, RSPG1: Rhizoctonia solani, SDPG: Glycinemax. Figure S5. Phylogenetic analysis of OsPG1 with other homologues in rice. Figure S6. Cell wall structure of leaf bottom, middle, and tip Statistical analysis of the primary cell wall, secondary cell wall, and middle lamella thicknesses of bundle sheath fiber cells in leave bottom(A), middle(B), and tip(C) of WT and Itn-212. Data are means \pm SD of 20 cells. ${ }^{* *}$ indicates significance at $P \leq 0.01$. Table S1.

Primers used in this study.

\section{Acknowledgements}

We thank Quanzhi Zhao, Junzhou Li (Henan Agricultural University) for providing opportunity to study at CNRRI. We also thank Bio-Ultrastructure Analysis Lab. of Analysis Center of Agrobiology and Environmental Sciences, Zhejiang Univ. for TEM observation.

\section{Authors' Contributions}

$C L, W X, C S, C Y, L Q, Z Y$ designed the research. CY, LQ, ZY, CY, YN, ZY, WW, CD performed the research and analyzed the data. $C Y, L Q, C L, W X, C S$ wrote the manuscript and revised the manuscript. All authors have read the manuscript and approved to submit it to your journal.

\section{Funding}

National Natural Science Foundation of China (31801726, 31871236, and 31521064), the National Key Transgenic Program (2016ZX08001002), and the Agricultural Science and Technology Innovation Program of the Chinese Academy of the Agricultural Sciences (CAAS-ASTIP-2013-CNRRI). the Fundamental Research Funds of Central Public Welfare Research Institutions (2017RG001-1).

Availability of Data and Materials

All relevant data are provided within the article and its supplementary information files.

\section{Declarations}

Ethics Approval and Consent to Participate

Not applicable.

Consent for Publication

Not applicable.

\section{Competing Interests}

The authors declare that they have no competing interests.

\section{Author details}

'State Key Laboratory of Rice Biology, China National Rice Research Institute, Zhejiang 310006, Hangzhou, China. 'Key Laboratory for Zhejiang Super Rice Research, China National Rice Research Institute, Zhejiang 310006, Hangzhou, China. 
Received: 27 August 2020 Accepted: 1 April 2021

\section{Published online: 21 April 2021}

\section{References}

Annis SL, Goodwin PH (1997) Recent advances in the molecular genetics of plant cell wall-degrading enzymes produced by plant pathogenic fungi. Eur J Plant Pathol 103(1):1-14. https://doi.org/10.1023/A:1008656013255

Atkinson RG, Schroder R, Hallett IC, Cohen D, MacRae EA (2002) Overexpression of Polygalacturonase in transgenic apple trees leads to a range of novel phenotypes involving changes in cell adhesion. Plant Physiol 129(1):122-133. https://doi.org/10.1104/pp.010986

Atmodjo MA, Hao ZY, Mohnen D (2013) Evolving views of pectin biosynthesis. Annu Rev Plant Biol 64(1):747-779. https://doi.org/10.1146/annurev-arplant042811-105534

Bacete L, Melida H, Miedes E, Molina A (2018) Plant cell wall-mediated immunity: cell wall changes trigger disease resistance responses. Plant J 93(4):614-636. https://doi.org/10.1111/tpj.13807

Bellincampi D, Cervone F, Lionetti V (2014) Plant cell wall dynamics and wallrelated susceptibility in plant-pathogen interactions. Front Plant Sci 5:228228

Bonnin E, Garnier C, Ralet M (2014) Pectin-modifying enzymes and pectin-derived materials: applications and impacts. Applied microbiology. Biotechnology 98: 519-532

Cantu D, Vicente AR, Labavitch JM, Bennett AB, Powell ALT (2008) Strangers in the matrix: plant cell walls and pathogen susceptibility. Trends Plant Sci 13(11):610-617. https://doi.org/10.1016/j.tplants.2008.09.002

Engelsdorf T, Will C, Hofmann J, Schmitt C, Merritt BB, Rieger L, Frenger MS, Marschall A, Franke R, Pattathil S (2016) Cell wall composition and penetration resistance against the fungal pathogen Colletotrichum higginsianum are affected by impaired starch turnover in Arabidopsis mutants. J Exp Bot 68:701-713

Ferrari S, Galletti R, Pontiggia D, Manfredini C, Lionetti V, Bellincampi D, Cervone F, De LG (2007) Transgenic expression of a fungal endo-Polygalacturonase increases plant resistance to pathogens and reduces Auxin sensitivity. Plant Physiol 146:669-681

Gallegogiraldo L, Liu C, Posealbacete S, Pattathil S, Peralta AG, Young J, Westpheling J, Hahn MG, Rao XL, Knox JP, Knox JP, Meester BD, Boerjan W, Dixon RA (2020) ARABIDOPSIS DEHISCENCE ZONE POLYGALACTURONASE 1 (ADPG1) releases latent defense signals in stems with reduced lignin content. Proc Natl Acad Sci U S A 117(6):3281-3290. https://doi.org/10.1073/ pnas. 1914422117

Gunawardena AH, Greenwood JS, Dengler NG (2007) Cell wall degradation and modification during programmed cell death in lace plant, APONOGETON MADAGASCARIENSIS (APONOGETONACEAE). Am J Bot 94(7):1116-1128. https://doi.org/10.3732/ajb.94.7.1116

Hadfield KA, Bennett AB (1998) Polygalacturonases: many genes in search of a function. Plant Physiol 117(2):337-343. https://doi.org/10.1104/pp.117.2.337

He YJ, Karre S, Johal GS, Christensen SA, Balint-Kurti P (2019) A maize polygalacturonase functions as a suppressor of programmed cell death in plants. BMC Plant Biol 19(1):310. https://doi.org/10.1186/s12870-019-1897-5

Hong YB, Zhang YX, Sinumporn S, Yu N, Xd Z, Shen XH, Chen DB, Yu P, Wu WX, Liu QE, Cao ZY, Zhao CD, Cheng SH, Cao LY (2018) Premature leaf senescence 3 , encoding a methyltransferase, is required for melatonin biosynthesis in rice. Plant J 95(5):877-891. https://doi.org/10.1111/tpj.13995

Hongo S, Sato K, Yokoyama R, Nishitani K (2012) Demethylesterification of the primary wall by PECTIN METHYLESTERASE35 provides mechanical support to the Arabidopsis stem. Plant Cell 24(6):2624-2634. https://doi.org/10.1105/tpc.112.099325

Hu B, Zhu CG, Li F, Tang JY, Wang YQ, Lin AH, Liu LC, Che RH, Chu CC (2011) LEAF TIP NECROSIS1 plays a pivotal role in the regulation of multiple phosphate starvation responses in rice. Plant Physiol 156(3):1101-1115. https://doi.org/10.1104/pp.110.170209

Itoh J, Nonomura K, Ikeda K, So Y, Inukai Y, Yamagishi H, Kitano H, Nagato Y (2005) Rice plant development from zygote to spikelet. Plant Physiology Cell 46(1):23-47. https://doi.org/10.1093/pcp/pci501

Jia HF, Ren HY, Gu M, Zhao JN, Sun SB, Zhang X, Chen JY, Wu P, Xu GH (2011) The phosphate transporter gene OsPht1;8 is involved in phosphate homeostasis in Rice. Plant Physiol 156(3):1164-1175. https://doi.org/10.1104/ pp. 111.175240

Kesten C, Menna A, Sanchezrodriguez C (2017) Regulation of cellulose synthesis in response to stress. Curr Opin Plant Biol 40:106-113. https://doi.org/10.10 6/j.pbi.2017.08.010
Kim J, Shiu S, Thoma S, Li W, Patterson SE (2006) Patterns of expansion and expression divergence in the plant polygalacturonase gene family. Genome Biol 7:1-14

Krattinger SG, Sucher J, Selter LL, Chauhan H, Zhou B, Tang MZ, Upadhyaya NM, Mieulet D, Guiderdoni E, Weidenbach D, Schaffrath U, Lagudah ES, Keller B (2016) The wheat durable, multipathogen resistance gene Lr34 confers partial blast resistance in rice. Plant Biotechnol J 14(5):1261-1268. https://doi.org/1 $0.1111 /$ pbi.12491

Leng YJ, Yang YL, Ren DY, Huang LC, Dai LP, Wang YQ, Chen L, Tu ZJ, Gao YH, Li XY, Zhu L, Hu J, Zhang GH, Gao ZY, Guo LB, Kong ZS, Lin YJ, Qian Q, Zeng DL (2017) A Rice PECTATE LYASE-LIKE gene is required for plant growth and leaf senescence. Plant Physiol 174(2):1151-1166. https://doi.org/10.1104/pp.16.01625

Li JG, Zhu H, Yuan RC (2010) Profiling the expression of genes related to ethylene biosynthesis, ethylene perception, and cell wall degradation during fruit abscission and fruit ripening in apple. J Am Soc Hortic Sci 135(5):391401. https://doi.org/10.21273/JASHS.135.5.391

Lionetti V, Fabri E, De CM, Hansen AR, Willats WGT, Piro G, Bellincampi D (2017) Three pectin Methylesterase inhibitors protect Cell Wall integrity for Arabidopsis immunity to Botrytis. Plant Physiol 173(3):1844-1863. https://doi. org/10.1104/pp.16.01185

Liu H, Ma Y, Chen NA, Guo SY, Liu HL, Guo XY, Chong K, Xu YY (2014) Overexpression of stress-inducible OsBURP16, the $\beta$ subunit of polygalacturonase 1 , decreases pectin content and cell adhesion and increases abiotic stress sensitivity in rice. Plant Cell Environ 37(5):1144-1158. https://doi.org/10.1111/pce.12223

Liu H, Wang Y, Xu J, Su T, Liu G, Ren D (2008) Ethylene Signaling is required for the acceleration of cell death induced by the activation of AtMEK5 in Arabidopsis. Cell Res 18:422-432. https://doi.org/10.1038/cr.2008.2.

Liu Hk, Qian M, Song CH, Li JJ, Zhao CP, Li GF, Wang AZ, Han MY (2018) DownRegulation of PpBGAL10 and PpBGAL16 Delays Fruit Softening in Peach by Reducing Polygalacturonase and Pectin Methylesterase Activity. Frontiers in Plant Science 9:1015.

Liu QE, Ning YS, Zhang YX, Yu N, Zhao CD, Zhan XD, Wu WX, Chen DB, Wei XJ, Wang GL, Cheng SH, Cao LY (2017) OsCUL3a Negatively Regulates Cell Death and Immunity by Degrading OsNPR1 in Rice. Plant Cell. 29:345-359. https://doi.org/10.1105/tpc.16.00650.

Ma J, Wang YF, Ma XD, Meng LZ, Jing RN, Wang F, Wang S, Cheng ZJ, Zhang X, Jiang L, Zhao ZC, Guo XP, Lin QB, Wu FQ, Zhu SS, Wu CY, Ren YL, Lei CL, Zhai HQ, Wan JM (2019) Disruption of gene SPL35, encoding a novel CUE domain-containing protein, leads to cell death and enhanced disease response in rice. Plant Biotechnol J 17(8):1679-1693. https://doi.org/10.1111/pbi.13093

Malinovsky FG, Fangel JU, Willats WGT (2014) The role of the cell wall in plant immunity. Front Plant Sci 5:178-178

Marinrodriguez MC, Orchard J, Seymour GB (2002) Pectate lyases, cell wall degradation and fruit softening. J Exp Bot 53(377):2115-2119. https://doi. org/10.1093/jxb/erf089

Markovic O, Janecek S (2001) Pectin degrading glycoside hydrolases of family 28: sequence-structural features, specificities and evolution. Protein Eng 14(9): 615-631. https://doi.org/10.1093/protein/14.9.615

Mccarthy TW, Der JP, Honaas LA, Depamphilis CW, Anderson CT (2014) Phylogenetic analysis of pectin-related gene families in Physcomitrella patens and nine other plant species yields evolutionary insights into cell walls. BMC Plant Biol 14(1):79-79. https://doi.org/10.1186/1471-2229-14-79

Micheli F (2001) Pectin methylesterases: cell wall enzymes with important roles in plant physiology. Trends Plant Sci 6(9):414-419. https://doi.org/10.1016/S13 60-1385(01)02045-3

Miedes E, Vanholme R, Boerjan W, Molina A (2014) The role of the secondary Cell Wall in plant resistance to pathogens. Front Plant Sci 5:358-358

Ogawa M, Kay P, Wilson S, Swain SM (2009) ARABIDOPSIS DEHISCENCE ZONE POLYGALACTURONASE1 (ADPG1), ADPG2, and QUARTET2 are polygalacturonases required for cell separation during reproductive development in Arabidopsis. Plant Cell 21(1):216-233. https://doi.org/10.1105/tpc.108.063768

Peaucelle A, Braybrook SA, Hofte H (2012) Cell wall mechanics and growth control in plants: the role of pectins revisited. Front Plant Sci 3:121-121

Quesada MA, Blancoportales R, Pose S, Garciagago JA, Jimenezbermudez S, Munozserrano A, Caballero JL, Pliegoalfaro F, Mercado JA, Munozblanco J (2009) Antisense Down-regulation of the FaPG1 gene reveals an unexpected central role for Polygalacturonase in strawberry fruit softening. Plant Physiol 150(2):1022-1032. https://doi.org/10.1104/pp.109.138297

Rani MH, Liu QE, Yu N, Zhang YX, Wang BF, Cao YR, Zhang Y, Islam A, Anley ZW, Cao Liyong Cheng SH (2020) ES5 is involved in the regulation of 
phosphatidylserine synthesis and impacts on early senescence in rice (Oryza sativa L). Plant Mol Biol 102(4-5):501-515. https://doi.org/10.1007/s11103-019-00961-4

Rhee SY, Osborne E, Poindexter PD, Somerville CR (2003) Microspore separation in the quartet 3 mutants of Arabidopsis is impaired by a defect in a developmentally regulated polygalacturonase required for pollen mother cell wall degradation. Plant Physiol 133(3):1170-1180. https:/doi.org/10.1104/pp.103.028266

Risk JM, Selter LL, Chauhan H, Krattinger SG, Kumlehn J, Hensel G, Viccars L, Richardson T, Buesing G, Troller A, Lagudah ES, Beat K (2013) The wheat Lr34 gene provides resistance against multiple fungal pathogens in barley. Plant Biotechnol J 11(7):847-854. https://doi.org/10.1111/pbi.12077

Ruan BP, Hua ZH, Zhao J, Zhang B, Ren DY, Liu CL, Yang SL, Zhang AP, Jiang HZ, Yu HP, Hu J, Zhu L, Chen G, Shen L, Dong GJ, Zhang GH, Zeng DL, Guo LB, Qian Q, Gao ZY (2019) OsACL-A2 negatively regulates cell death and disease resistance in rice. Plant Biotechnol J 17(7):1344-1356. https://doi.org/10.1111/pbi.13058

Rui Y, Xiao CW, Yi H, Kandemir B, Wang JZ, Puri VM, Anderson CT (2017) POLYGALACTURONASE INVOLVED IN EXPANSION3 functions in seedling development, rosette growth, and Stomatal dynamics in Arabidopsis thaliana. Plant Cell 29(10):2413-2432. https://doi.org/10.1105/tpc.17.00568

Sarkar P, Bosneaga E, Auer M (2009) Plant cell walls throughout evolution: towards a molecular understanding of their design principles. J Exp Bot 60(13):3615-3635. https://doi.org/10.1093/jxb/erp245

Sathe AP, Su XN, Chen Z, Chen T, Wei XJ, Tang SQ, Zhang XB, Wu JL (2019) Identification and characterization of a spotted-leaf mutant sp/40 with enhanced bacterial blight resistance in rice. Rice 12:1-15

Singh RP (1992) Association between gene Lr34 for leaf rust resistance and leaf tip necrosis in wheat. Crop Sci 32(4):874-878. https://doi.org/10.2135/ cropsci1992.0011183X003200040008x

Somerville C, Bauer S, Brininstool G, Facette M, Hamann T, Milne J, Osborne E, Paredez A, Persson S, Raab T, Vorwerk S, Youngs H (2004) Toward a systems approach to understanding plant-cell walls. Science 306(5705):2206-2211. https://doi.org/10.1126/science.1102765

Van BF, Dat JF (2006) Reactive oxygen species in plant cell death. Plant Physiol 141:384-390

Villarreal NM, Martínez GA, Civello PM (2009) Influence of plant growth regulators on polygalacturonase expression in strawberry fruit. Chin Academy Agric Sci 176:0-757

Vogel JP, Raab TK, Schiff C, Somerville SC (2002) PMR6, a Pectate Lyase-like gene required for powdery mildew susceptibility in Arabidopsis. Plant Cell 14(9): 2095-2106. https://doi.org/10.1105/tpc.003509

Wakasa Y, Kudo H, Ishikawa R, Akada S, Senda M, Niizeki M, Harada T (2006) Low expression of an endopolygalacturonase gene in apple fruit with long-term storage potential. Technol Postharvest Biol 39(2):193-198. https://doi.org/10.1 016/j.postharvbio.2005.10.005

Wang X, Hou SG, Wu QQ, Lin MY, Acharya BR, Wu DJ, Zhang W (2017) IDL6-HAE/ HSL2 impacts pectin degradation and resistance to Pseudomonas syringae pv tomato DC3000 in Arabidopsis leaves. Plant J 89(2):250-263. https://doi.org/1 $0.1111 /$ tpj. 13380

Wang YQ, Wan ZY, CAO JS, YU Xiao-Lin, XIANG X, LU G (2005) Cloning and characterization of the microspore development-related gene BCMF2 in Chinese cabbage Pak-Choi (Brassica campestris L. ssp. chinensis Makino). J Integr Plant Biol, 47: 863-872, 7, DOl: https://doi.org/10.1111/j.1744-7909.2005.00101.x

Wolf S, Gregory M, Jerome P (2009) Homogalacturonan methyl-esterification and plant development. Mol Plant 2(5):851-860. https://doi.org/10.1093/mp/ssp066

Wu LW, Ren DY, Hu SK, Li GG, Dong GJ, Jiang L, Hu XM, Ye WJ, Cui YT, Zhu L, Hu J, Zhang GH, Gao ZY, Zeng DL, Qian Q, Guo LB (2016) Down-regulation of a Nicotinate Phosphoribosyltransferase gene, OsNaPRT1, leads to withered leaf tips. Plant Physiol 171(2):1085-1098. https://doi.org/10.1104/pp.15.01898

Xiao CW, Barnes WJ, Zamil MS, Yi H, Puri VM, Anderson CT (2017) Activation tagging of Arabidopsis POLYGALACTURONASE INVOLVED IN EXPANSION2 promotes hypocotyl elongation, leaf EXPANSION, stem lignification, mechanical stiffening, and lodging. Plant J 89(6):1159-1173. https://doi.org/10.1111/tpj.13453

Xiao CW, Somerville C, Anderson CT (2014) POLYGALACTURONASE INVOLVED IN EXPANSION1 functions in cell elongation and flower development in Arabidopsis. Plant Cell 26(3):1018-1035. https://doi.org/10.1105/tpc.114.123968

Zurbriggen MD, Carrillo N, Hajirezaei M (2010) ROS signaling in the hypersensitive response: when, where and what for? Plant Signal Behav 5(4): 393-396. https://doi.org/10.4161/psb.5.4.10793

\section{Publisher's Note}

Springer Nature remains neutral with regard to jurisdictional claims in published maps and institutional affiliations.

\section{Submit your manuscript to a SpringerOpen ${ }^{\circ}$ journal and benefit from:}

- Convenient online submission

- Rigorous peer review

- Open access: articles freely available online

- High visibility within the field

- Retaining the copyright to your article

Submit your next manuscript at $\boldsymbol{\nabla}$ springeropen.com 